\title{
The preparation of nutritious protein from wool
}

\author{
By F. B. SHORLAND* AND JUDITH M. GRAY* \\ Food Chemistry Division, Department of Scientific and Industrial \\ Research, Wellington, New Zealand
}

(Received 3 November 1969-Accepted 3 February 1970)

\begin{abstract}
I. The nutritive value of solubilized wool protein prepared by dissolving finely ground wool in sodium sulphide-sodium sulphite solution followed by precipitation with $40 \%$ acetic acid has been tested by incorporating it into protein-free diets containing the amounts of vitamins and minerals required by weanling rats.

2. At the level of $10 \%(w / w)$ of the diet, solubilized wool protein failed to support growth in weanling rats, but when the diet was fortified with histidine, methionine and lysine a protein efficiency ratio of up to $\mathrm{I} \cdot 8$ was obtained. The effect of the addition of lysine was marginal. Similar results were obtained with solubilized wool protein prepared from dyed wool suiting material.

3. Apart from the methionine content, which varied from 0.49 to $0.66 \mathrm{~g} / 100 \mathrm{~g}$ protein, the contents of the essential amino acids in the solubilized wool protein generally met the requirement of the FAO (I957) provisional pattern, although in many of the preparations the levels of isoleucine and lysine were marginal. The tryptophan content was not determined. Supplementation of the solubilized wool protein with lysine to the level of $6-10 \mathrm{~g} / \mathrm{roO} \mathrm{g}$ protein slightly enhanced the nutritive value.
\end{abstract}

Interest in the conversion of wool into edible protein arises from the fact that the protein is not only cheap but available in quantities considerably in excess of those produced from lamb and mutton (Shorland, 1968, 1969). It has already been shown that wool protein solubilized by chemical or enzymic treatment after recovery by precipitation may be converted into a digestible protein-rich flour for incorporation into foods. When used to substitute up to $35 \%$ of the wheat flour in a variety of products, including scones, bread, sponge cakes and ginger biscuits, the acceptability of the product by human beings was found to be substantially unchanged (Shorland \& Bentley, 1969).

The results of feeding chemically or enzymically solubilized wool as a source of protein to weanling rats in diets containing all the non-protein nutrients have been disappointing as the animals failed to grow (Shorland \& Matthews, I968 and unpublished results). Experiments using equal parts of wool protein and tripe protein as the sole source of protein suggested that the solubilized wool protein was not toxic. At a level of $15 \%$ protein in the diet, ten rats of mean weight $75 \mathrm{~g}$ grew to a mean weight of $97 \mathrm{~g}$ in $10 \mathrm{~d}$.

In a preliminary communication, Shorland \& Gray ( 1969 ) reported that wool protein, when suitably prepared and fortified with essential amino acids (mainly methionine) up to the level of the FAO (I957) provisional pattern and with the addition of histidine to the level of $2 \cdot 3 \mathrm{~g} / \mathrm{r} 6 \mathrm{~g} \mathrm{~N}$ (cf. National Research Council, 1963), was nutritionally adequate as a source of protein for rats.

* Present address: Department of Biochemistry, Victoria University, Wellington, New Zealand. 
The present paper describes in more detail the results of the preliminary communication and outlines investigations on the level of supplementation of methionine and of lysine required for the optimum growth of rats using solubilized wool as the sole source of protein.

\section{EXPERIMENT AL}

\section{Materials}

Wool used for this work came from the same batch as was used in previous investigations (Shorland \& Matthews, I968), i.e. a scoured cross-bred sample. The residual grease was removed by continuous extraction with boiling acetone. The fibres were reduced to about $12 \mathrm{~mm}$ in length by guillotining them; they were further shortened to about $3 \mathrm{~mm}$ by means of a Christy \& Norris mill fitted with a special stainless steel cutter (cf. Shorland \& Matthews, 1968).

\section{Preparation of solubilized wool protein}

The preparation was based on the procedure of Koerner, Ehrhardt, Haigh \& Kirchof (1952). This involved pretreatment of the finely divided fat-free wool prepared as described above with $4.25 \mathrm{~N}-\mathrm{HCl}$ at $27^{\circ}$. After it had been washed with water, dilute $\mathrm{I} \% \mathrm{NaHCO}_{3}$ solution and again several times with water on a Buchner funnel using a No. I Whatman filter-paper, the wool was transferred to a flask with the addition of approximately ten times its weight of water. $\mathrm{Na}_{2} \mathrm{~S}, 6 \cdot 25$ parts $(\mathrm{w} / \mathrm{w})$, and $\mathrm{Na}_{2} \mathrm{SO}_{3}$, I 4 parts (w/w), per Ioo parts of wool were added with shaking, whereupon the $\mathrm{pH}$ of the solution rose to 12 , but was quickly brought back to 9.2 with the addition of $40 \%$ acetic acid. After digesting the mixture for $\mathrm{I}-2 \mathrm{~h}$ at $60^{\circ}$, it was filtered on a Buchner funnel with a No. 54 Whatman filter-paper and the residue was washed several times with water.

The $\mathrm{pH}$ of the filtrate was reduced to approximately 5.0 with acetic acid. The precipitated protein was then recovered by filtration on a Buchner funnel with a No. 54 paper and washed several times with water at $60^{\circ}$. To remove the last traces of chemicals, the precipitate was transferred to a beaker and stirred with about ten times its weight of water at $60^{\circ}$ using a Silverson Mixer-Homogenizer fitted with a standard head (Silverson Machines, Tower Bridge Road, London, SE I, England). The mixture was transferred to a Buchner funnel, filtered and washed.

This procedure was repeated several times using, finally, $95 \%$ redistilled alcohol. The solubilized wool protein was dried at $27^{\circ}$ in a current of air overnight and then ground in a micro-ball mill (Glen Creston, Stanmore, England) to pass a I $20(0.125 \mathrm{~mm})$ mesh sieve. The solubilized wool protein containing approximately $10 \%$ moisture was mixed with the other components of the diet and passed through a domestic flour sifter several times to obtain a homogeneous mixture. The yield of protein was up to $91 \%$ of the amount present in the untreated wool.

By means of the procedures outlined above, solubilized wool protein was also prepared from dyed wool fabric used as a suiting material. In order to solubilize the fabric material it was necessary to subject it to the sodium sulphide-sodium sulphite digestion solution several times. Further preparations of solubilized wool protein were made 
enzymically using papain as outlined by Shorland \& Bentley (1969). The solubilized protein thus prepared was separated from the insoluble protein by filtration.

\section{Amino acid analysis of the solubilized wool protein preparations}

The samples were hydrolysed by the procedure of Hirs, Stein \& Moore (1954). After making the hydrolysates up to standard volume with $\mathrm{pH} 2$ buffer solution, a suitable volume (usually $0.2 \mathrm{ml}$ ) was applied to a Beckman $120 \mathrm{C}$ Amino Acid Analyser. Typical results are given in Table $\mathrm{r}$.

\section{Table I. Amino acid composition of wool and of solubilized wool preparations ( $g$ amino acid/100 g amino acids)}

\begin{tabular}{|c|c|c|c|c|}
\hline Amino acid & $\begin{array}{c}\text { FAO } \\
\text { (I957) } \\
\text { provisional } \\
\text { pattern }\end{array}$ & $\begin{array}{l}\text { Solubilized } \\
\text { wool protein* }\end{array}$ & $\begin{array}{l}\text { Solubilized } \\
\text { off-cuts from } \\
\text { dyed woollen } \\
\text { cloth }\end{array}$ & $\begin{array}{c}\text { Wool } \\
\text { (Corfield \& } \\
\text { Robson, } \\
\text { I955)† }\end{array}$ \\
\hline
\end{tabular}

Essential:

Histidine

Isoleucine

Leucine

$0.91(0.17)$

$3.76(0.38)$

$8.38(0.45)$

Lysine

Phenylalanine

$3 \cdot 76(0.38)$

$3.52(0.15)$

Tyrosine

Methionine

$4.00(0.70)$

$0.57(0.17)$

Cystine

Threonine

Tryptophan

$5.93(0.40)$

$6.40(0.45)$

$5.32(0.33)$

I. OI

$3 \cdot 27$

$7 \cdot 44$

4.00

$3 \cdot 15$

4.29

0.49

6.05

$6 \cdot 15$

Valine

$2 \cdot 8$

I 4

$4 \cdot 2$

$5 \cdot 74$

Non-essential:

Arginine

Aspartic acid

$\begin{array}{rr}- & 10.42(0.61) \\ - & 7.25(0.56)\end{array}$

Serine

Glutamic acid

$7 \cdot 71(0 \cdot 25)$

$16.04(0.80)$

$6 \cdot 34(0.49)$

$4 \cdot 10(0.50)$

Glycine

$4.14(0.42)$

Alanine

$\mathrm{I} \cdot 32(0.18)$

$5 \cdot 7$

$\begin{array}{ll}9 \cdot 15 & 9 \cdot 8 \\ 7 \cdot 55 & 6 \cdot 8\end{array}$

$\begin{array}{ll}9 \cdot 15 & 9 \cdot 8 \\ 7 \cdot 55 & 6 \cdot 8\end{array}$

$8.43 \quad 9.9$

$16 \cdot 38 \quad 14 \cdot 5$

$6.51 \quad 6.8$

$4.80 \quad 5.5$

4.17

$\mathrm{NH}_{3}$

* Mean values for five preparations with standard deviation in parentheses.

$\uparrow$ Results expressed as $\mathrm{g}$ amino acid/ı00 $\mathrm{g}$ wool.

In the procedure used for amino acid analysis tryptophan was not determined. Using the Goodwin \& Morton (1946) colorimetric method, no detectable change in the tryptophan content was found after conversion of the wool protein into the solubilized form. Table I shows that most of the amino acids in the solubilized wool protein meet the levels required by the FAO (1957) provisional pattern. Methionine was found to be deficient, while isoleucine and lysine generally fell slightly below the required levels. Although histidine is not included in the FAO provisional pattern, a requirement for rats of $2 \cdot 3 \mathrm{~g} / \mathrm{ro0} \mathrm{g}$ protein, which is greatly in excess of the amount found (see Table I) in the solubilized wool proteins, is indicated (cf. National Research Council, 1963). The results for the amino acid composition of the solubilized off-cuts 
from dyed woollen cloth appear to agree closely with those obtained for the solubilized wool protein as well as with those given by Corfield \& Robson (1955) for untreated wool.

\section{Animals}

Weanling rats of the Wistar strain were obtained either from the Animal Research Centre, Wallaceville or from the Medical School, University of Otago, Dunedin. To accustom the animals to the finely divided meal, the stock diet 86 , provided in pellet form, was reduced to powder by mincing and given over a period of several days immediately before the experiment began. Toavoid undue spillage, the diet was placed in feeding bins $6.4 \mathrm{~cm}$ deep and $6.4 \mathrm{~cm}$ in diameter. The hole in the top was $3.2 \mathrm{~cm}$ in diameter. The rats were fed individually in separate cages at $2 \mathrm{I}^{\circ} \pm 3^{\circ}$. The rats were fed $a d$ lib., the amount given being adjusted so that the bins were almost empty each day when the fresh diet was weighed into them. Diet 86 was supplied by the Westfield Freezing Works, Auckland, and consisted of ( $\%$ by weight): whole-ground wheat, 50; whole-ground barley, 25; white fish meal, 7; meat-and-bone meal, 6; brewers yeast, 5 ; grass meal, 5 ; cod-liver oil, I and salts, I. The standard diet comprised ( $\%$ by weight) solubilized wool protein (SWP), ro; fat (equal parts of lard and maize oil), 5 ; fibre (Polyfilla cellulose powder), 5 ; mineral mixture, 5 ; vitamin mixture, 2.5 ; and maize starch up to Ioo.

The solubilized wool protein preparations contained approximately $80 \%$ protein, the remaining constituents being mainly water and minerals. The amount of the preparation included in the diet was therefore adjusted to give a total content of $10 \%$ protein in the diet.

The maize starch was found to contain not more than $0.1 \%$ protein.

The mineral mixture was made up as described by Green, Diplock, Bunyan, McHale \& Muthy (I967). The vitamin mixture was that recommended by Miller \& Bender (1955). The amino acids used as supplements were L-lysine monohydrochloride from British Drug Houses Ltd (chromatographically homogeneous), Lhistidine, L-methionine and L-tryptophan ("puriss' quality; Koch-Light Ltd). All the vitamin and mineral constituents were of analytical reagent quality.

\section{Feeding trials}

These were of three different types: (a) preliminary trials to indicate the effectiveness of the diet as judged from the growth rate of two rats, $(b)$ trials with groups of six rats to determine the optimum level of supplementation of limiting amino acids in the SWP diets using growth rate as the criterion, and $(c)$ trials with groups of six rats to determine the protein efficiency ratio (PER) of the SWP diet at the optimum level of supplementation using the procedures outlined by Bender (1958) and by Gangal \& Magar (1967). 
RESULTS

\section{Preliminary trials on the effects of adding amino acids to the standard diet containing $10 \% S W P$ as the sole source of protein}

In these tests the standard diet containing SWP with and without the addition of methionine and histidine was tested by feeding it ad lib. to weanling rats.

It will be seen from Table 2 that rats fed the standard SWP diet without amino acid supplementation failed to gain weight. After addition of histidine and methionine to

Table 2. Rate of growth of rats given diets containing solubilized wool protein (10\% diet) as the sole source of protein

(Histidine and methionine were added in the supplements in amounts bringing the total contents of these acids up to $2 \cdot 3$ and $2.0 \mathrm{~g} / \mathrm{l} 00 \mathrm{~g}$ protein respectively)*

\begin{tabular}{|c|c|c|c|c|}
\hline Diet & $\begin{array}{l}\text { Wt at } \\
\text { beginning } \\
\text { of Expt }(\mathrm{g})\end{array}$ & $\begin{array}{l}\text { Wt at end } \\
\text { of Expt }(\mathrm{g})\end{array}$ & $\underset{\text { (g/rat d) }}{\text { Gain }}$ & $\begin{array}{l}\text { Period of } \\
\text { observation } \\
\text { (d) }\end{array}$ \\
\hline Unsupplemented with amino acids & $\begin{array}{l}88.6 \\
88.0\end{array}$ & $\begin{array}{l}89 \cdot 1 \\
82 \cdot 1\end{array}$ & - & $\begin{array}{l}10 \\
10\end{array}$ \\
\hline Supplemented & $\begin{array}{l}67 \cdot 2 \\
73 \cdot 3 \\
58 \cdot 9 \\
56 \cdot 3\end{array}$ & $\begin{array}{l}8 \mathrm{r} \cdot 6 \\
99 \cdot 0 \\
67 \cdot 2 \\
73 \cdot 3\end{array}$ & $\begin{array}{l}I \cdot 6 \\
2 \cdot 9 \\
I \cdot I \\
I \cdot 3\end{array}$ & $\begin{array}{l}9 \\
9 \\
9 \\
9\end{array}$ \\
\hline Supplemented $\uparrow$ & $\begin{array}{l}70.5 \\
70.6\end{array}$ & $\begin{array}{l}92 \cdot 5 \\
90 \cdot 1\end{array}$ & $\begin{array}{l}I \cdot 5 \\
I \cdot 3\end{array}$ & $\begin{array}{l}\text { I5 } \\
\text { I5 }\end{array}$ \\
\hline
\end{tabular}

* In this experiment groups of two rats only were used for the tests on the solubilized wool protein unsupplemented with amino acids and on the supplemented solubilized wool protein prepared from dyed woollen cloth. In the experiments outlined in Tables 3-5 groups of six rats were involved.

+ The solubilized wool protein in this test was prepared from dyed (blue) woollen cloth used for suiting.

the diet the rats gained from $\mathrm{I} \cdot \mathrm{I}$ to $2 \cdot 9 \mathrm{~g} / \mathrm{d}$. Similar results were obtained with SWP prepared from dyed suiting material. It was also found that solubilized wool protein prepared by means of papain (cf. Shorland \& Bentley, 1969) produced, after fortification with histidine and methionine, weight gains, whereas the insoluble residue, similarly fortified, failed to induce growth when used as the sole source of protein.

\section{Determination of the optimum level of supplementation of methionine and lysine in SWP preparations}

The results of feeding methionine at five different levels are shown in Table 3.

It will be seen that the maximum growth rate was achieved when the total methionine content of the diet reached $2.0 \mathrm{~g} / \mathrm{r} 00 \mathrm{~g}$ protein. With this level of methionine, the most effective concentration of lysine was determined by adding this amino acid at five different levels to the SWP diet.

As shown in Table 4, fortification of the SWP diet with lysine slightly increased the rate of growth of the rats. The most effective level appeared to be about 6-10 g/ $100 \mathrm{~g}$ protein. 
Table 3. Effect of methionine supplementation on diets containing solubilized wool protein (SWP), ro \% based on protein content, as the sole source of protein

(Histidine was added to give a concentration of $2.3 \mathrm{~g} / \mathrm{roO} \mathrm{g}$ protein. The diets containing SWP were given for a period of $14 \mathrm{~d}$ )

\begin{tabular}{|c|c|c|c|c|}
\hline $\begin{array}{l}\text { Wt of } \\
\text { methionine } \\
\text { added } \\
\text { (g/10o }\end{array}$ & $\begin{array}{l}\text { Total wt } \\
\text { methionine } \\
\text { protein) }\end{array}$ & $\begin{array}{c}\text { Wt of rats } \\
\text { after } 6 \mathrm{~d} \text { on } \\
\text { diet containing } \\
\text { SWP }(\mathrm{g})^{*}\end{array}$ & $\begin{array}{c}\text { Wt of } \\
\text { rats at end } \\
\text { of } \\
\text { Expt }(g)^{*}\end{array}$ & $\begin{array}{c}\text { Gain/rat } \\
\mathrm{d}(\mathrm{g}) \dagger\end{array}$ \\
\hline 0.4 & $I \cdot O$ & $65 \cdot 5(7 \cdot 7)$ & $74 \cdot 9(7 \cdot 9)$ & $I \cdot 2$ \\
\hline 0.9 & $I \cdot 5$ & $65.5(2 \cdot 9)$ & $75^{\circ} 9\left(5^{\circ} 0\right)$ & $1 \cdot 3$ \\
\hline $1 \cdot 4$ & $2 \cdot 0$ & $60 \cdot 8(4 \cdot 5)$ & $73 \cdot 9(7 \cdot 7)$ & $I \cdot 6$ \\
\hline $2 \cdot 4$ & 3.0 & $57 \cdot 6(8 \cdot 4)$ & $67 \cdot 7(8 \cdot 9)$ & $I \cdot 3$ \\
\hline $4 \cdot 4$ & 5.0 & $56 \cdot 0(7 \cdot 7)$ & $66 \cdot 3(6 \cdot 9)$ & $I \cdot 3$ \\
\hline
\end{tabular}

* Mean values for six rats with standard deviations in parentheses.

$\uparrow$ Determined by the method of least squares.

Table 4. Effect of lysine supplementation on diets containing solubilized wool protein $(S W P), 10 \%$ based on protein content, as the sole source of protein

(Histidine and methionine were added to raise the levels of these amino acids to $2 \cdot 3$ and $2.0 \mathrm{~g} / 100 \mathrm{~g}$ protein respectively. The SWP was given for a period of $\mathrm{I} 4 \mathrm{~d}$ )

\begin{tabular}{|c|c|c|c|c|c|}
\hline $\begin{array}{l}\text { Wt of } \\
\text { lysine } \\
\text { added } \\
(\mathrm{g} / \mathrm{r} 00\end{array}$ & $\begin{array}{l}\text { Total } \\
\text { wt of } \\
\text { lysine } \\
\text { cotein) }\end{array}$ & $\begin{array}{c}\text { Wt of rats } \\
\text { after } 9 \mathrm{~d} \text { on } \\
\text { SWP diet }(\mathrm{g})^{*}\end{array}$ & $\begin{array}{l}\text { Wt of rats } \\
\text { at end of } \\
\text { Expt }(g)^{*}\end{array}$ & $\begin{array}{c}\text { Gain/rat } \\
\text { d (g) } \dagger\end{array}$ & $\begin{array}{l}\text { Protein } \\
\text { efficiency } \\
\text { ratio }\end{array}$ \\
\hline 0.2 & 4.0 & $78.3(10 \cdot 0)$ & $89 \cdot 8(10 \cdot 0)$ & $I \cdot 9$ & $I \cdot 6(0.2)$ \\
\hline $2 \cdot 2$ & $6 \cdot 0$ & $68 \cdot 8(\mathrm{I}$ I 8$)$ & $79 \cdot 9(14 \cdot I)$ & $2 \cdot 0$ & $1.8(0.2)$ \\
\hline $4 \cdot 2$ & $8 \cdot 0$ & $75 \cdot 1(5 \cdot 0)$ & $86 \cdot 7(6 \cdot I)$ & $2 \cdot 0$ & $1.8(0.3)$ \\
\hline $6 \cdot 2$ & $10 \cdot 0$ & $73 \cdot 3(7 \cdot 7)$ & $83 \cdot 4(7 \cdot 0)$ & $2 \cdot 5$ & I. $8(0.5)$ \\
\hline $8 \cdot 2$ & $12 \cdot 0$ & $78 \cdot 4($ 1 $3 \cdot 1)$ & $89.0(15 \cdot 8)$ & $2 \cdot 0$ & $I .5(0.6)$ \\
\hline
\end{tabular}

* Mean values for six rats with standard deviations in parentheses.

$\uparrow$ Determined by the method of least squares.

\section{Measurement of the protein efficiency ratio of SWP preparations}

In these experiments the SWP diet fortified with L-histidine, L-lysine, L-methionine and L-tryptophan, as shown in Table 5, was compared with diet 86 . At this stage it was not known whether the tryptophan content in the SWP had been affected by the method of preparation. It was subsequently found by the colorimetric method of Goodwin \& Morton (1946) that there was no detectable change in the tryptophan content after conversion of the protein into the solubilized form.

The results show that although diet 86 induced a faster growth rate $(3.9 \mathrm{~g} / \mathrm{rat}$ per $\mathrm{d})$ than the fortified SWP $\operatorname{diet}(2 \cdot 0 \mathrm{~g} /$ rat per d), the PER value was lower at $\mathrm{I} \cdot 2(0 \cdot 2) \mathrm{com}-$ pared with $I \cdot 7(0.2)$ found for the fortified SWP diet. The protein content of diet 86 was not only higher (19.8\%) than that of the SWP diet (10\%) but the amount of protein consumed per rat during the experiment was much greater $(6 \mathrm{I} \cdot 0 \mathrm{~g} \pm 6 \cdot 4 \mathrm{~g}$ (SD) compared with $22 \cdot 5 \mathrm{~g} \pm 0 \cdot 6 \mathrm{~g}$ (SD)). 
As shown in Table 4, PER values were also determined on the SWP diet containing the optimum level of histidine and methionine and varying levels of lysine. A maximum value of $\mathrm{r} \cdot 8$ for PER was attained at a lysine content of $6-10 \mathrm{~g} / \mathrm{IOO} \mathrm{g}$ protein with a small reduction to $\mathrm{I} \cdot 5$ when the lysine content reached $\mathrm{I} 2 \mathrm{~g} / \mathrm{I} 00 \mathrm{~g}$ protein. As the lysine levels increased, the variations in the response of individual rats also increased, as shown by the rising values of the standard deviations for the PER values.

Table 5. Comparison between the stock diet 86 and the standard diet in which SWP was the sole source of protein with the addition of L-histidine, L-lysine and L-methionine to bring the levels of these amino acids to $2 \cdot 3,4 \cdot 2$ and $2 \cdot 2 \mathrm{~g} / \mathrm{100} \mathrm{g}$ protein respectively and with the addition also of $\mathrm{I} \cdot 75 \mathrm{~g}$ tryptophan/100 $\mathrm{g}$ protein

(The diets were given for $19 \mathrm{~d}$; mean values for six rats with standard deviations in parentheses)

\begin{tabular}{|c|c|c|c|c|}
\hline Diet & $\begin{array}{l}\text { Wt of rats } \\
\text { at beginning of } \\
\text { Expt }(\mathrm{g})\end{array}$ & $\begin{array}{l}\text { Wt of rats } \\
\text { at end of } \\
\text { Expt (g) }\end{array}$ & $\begin{array}{c}\text { Gain/rat d } \\
\text { (g) }\end{array}$ & $\begin{array}{l}\text { Protein } \\
\text { efficiency } \\
\text { ratio }\end{array}$ \\
\hline $\begin{array}{l}\text { SWP with added } \\
\text { amino acids (ro\% } \\
\text { protein) }\end{array}$ & $7 I \cdot 0(4 \cdot I)$ & $108 \cdot 9(7 \cdot 8)$ & $2 \cdot 0(0 \cdot 4)$ & $1 \cdot 7(0 \cdot 2)$ \\
\hline $\begin{array}{l}\text { Stock diet } 86 \\
\text { (19.8\% protein) }\end{array}$ & $76 \cdot 6(5 \cdot 5)$ & $150.2(12.9)$ & $3.9(0.7)$ & $1 \cdot 2(0 \cdot 2)$ \\
\hline
\end{tabular}

\section{Digestibility of the solubilized wool protein}

The digestibility of the solubilized wool protein was determined as outlined by Miller \& Bender (1955) using the equation

$$
D=\frac{I-(F-F k)}{I},
$$

where $F$ and $F k$ are the faecal nitrogen values on the protein and non-protein diets respectively and $I$ is the intake on the protein diet. The rats used for this purpose were those fed solubilized wool protein supplemented with histidine, methionine, lysine and tryptophan as shown in Table 5. The intake and faecal nitrogen were measured daily and the basal faecal nitrogen value was determined on a similar group in which the protein had been excluded. The mean digestibility was $74 \cdot 6 \%$ ( $\mathrm{SD} \pm 3 \cdot 0 \%$ ).

\section{DISCUSSION}

The use of solubilized wool protein as the sole source of protein in the diet has been shown to be inadequate to maintain growth in rats. This confirms the observations of Shorland \& Matthews (I968). The lack of growth was probably not attributable to the presence of toxic factors because, as indicated above, when the dietary protein consisted of equal parts of SWP and of protein from the rumen tissues of sheep good growth in rats was maintained in the presence of adequate supplies of non-protein nutrients.

In comparison with the FAO (r957) provisional pattern of amino acids, solubilized wool protein was shown to be defective mainly in methionine (see Table I). The lysine 
and isoleucine contents of the SWP preparations were generally slightly deficient in comparison with the FAO (1957) provisional pattern but in some batches one or other of these amino acids was present at the desired level. The addition of tryptophan (Table 5) was based on the assumption that this amino acid could have been destroyed during preparation of the SWP. Further investigation by the method of Goodwin \& Morton (1946), however, did not indicate any loss of tryptophan. The addition of tryptophan to the SWP preparations appeared to be unwarranted and this was borne out by the feeding trials in which addition of this amino acid was omitted. The addition of lysine appeared to have little practical value in improving the nutritional value of the solubilized wool protein. For use in human food it would seem that fortification of the SWP with methionine alone is the main requirement. The admixture of SWP with natural protein sources such as rice, which is relatively rich in methionine, could provide a protein of somewhat better quality than would be possible by using rice or SWP alone.

When given the SWP diets, the rats usually did not grow during the first few days but thereafter gained steadily as they became accustomed to the new food. The PER values and the growth rates were therefore based on the period of steady growth rather than over the whole of the experimental period. The PER value of up to $\mathrm{I} \cdot 8$ obtained with SWP fortified with amino acids may be compared with those found by Bender (1956) as follows: dried defatted egg, $4^{\circ} 0$; beef powder, $2 \cdot 47$; dried skim milk, 2.28; bread +lysine, $I \cdot I 5$ and bread, $-0 \cdot 10$.

The possibility that the intake of the SWP diet was lower than normal is suggested by the tendency of the rats to take to this new food less avidly than to the stock diet. The relatively low intake of the SWP diet was also demonstrated by the fact that the rats on this diet ingested about $74 \%$ of the amount consumed by similar rats on diet 86. In the present work the SWP was finely ground to ensure maximum digestibility but no investigations on the relationship of fineness of grinding to nutritive value have been carried out. To judge from the growth rates, SWP prepared from dyed wool cloth used for suiting material was similar as a source of protein to that prepared from unprocessed defatted wool despite the presence of residual dye.

The authors acknowledge the skilled technical assistance of Mr H. S. Rubie and Miss P. A. Wilson. They also thank Mr P. D. Pearce for carrying out the amino acid analyses, and Dr M. B. Buddle, Superintendent, and Mr W. R. A. Poppleton of the Animal Research Centre, Department of Agriculture, Wallaceville for a generous supply of rats.

\section{REFERENCES}

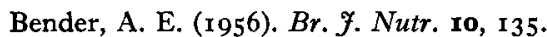

Bender, A. E. (1958). Proc. Nutr. Soc. 17, 85.

Corfield, M. C. \& Robson, A. (1955). Biochem. F. 59, 62.

FAO (1957). F.A.O. nutr. Stud. no. I6.

Gangal, S. V. \& Magar, N. G. (1967). Br. F. Nutr. 21, I.

Goodwin, T. W. \& Morton, R. A. (1946). Biochem. F. 40, 628.

Green, J., Diplock, A. T., Bunyan, J., McHale, D. \& Muthy, I. R. (I967). Br. F. Nutr. 2 , 69.

Hirs, C. H. W., Stein, W. H. \& Moore, S. (1954). J. biol. Chem. 211, 941. 
Vol. $24 \quad$ Preparation of nutritious protein from wool

Koerner, E. C., Ehrhardt, H., Haigh, P. \& Kirchof, J. (x952). U.S. Patent no. 2, $591,945$. Miller, D. S. \& Bender, A. E. (1955). Br. F. Nutr. 9, 382.

National Research Council (x963). Publs natn. Res. Coun., Wash. no. I 100.

Shorland, F. B. (I968). Fd Technol. N.Z. 5, to.

Shorland, F. B. (1969). Fd Mf. 44, 42.

Shorland, F. B. \& Bentley, K. W. (1969). Fd Technol. Aust. 21, 2 r 8.

Shorland, F. B. \& Gray, J. M. (1969). N.Z. fl Sci. 12, 647.

Shorland, F. B. \& Matthews, J. R. (r968). N.Z. $\mathscr{~ I l ~ S c i . ~ x I , ~ I 3 I . ~}$ 